\title{
Sensor Asam Nukleat Sebagai Aktivator Imunitas Intrinsik Terhadap Patogen Intraseluler
}

\author{
(Nucleic Acid Sensors as Activators of Intrinsic Immunity Against Intracellular Pathogens) \\ Usmar, Rudi Arfiansyah, dan Firzan Nainu* \\ Fakultas Farmasi, Universitas Hasanuddin, Makassar, Indonesia, 90245
}

\begin{tabular}{l} 
Article Info: \\
Received: 02 September 2017 \\
in revised form: 16 September 2017 \\
Accepted: 23 September 2017 \\
Available Online: 01 Oktober 2017 \\
\hline \\
Keywords: \\
DNA sensors \\
RNA sensors \\
Immunity to microbes \\
Resistance to immune system \\
Pharmaceutical preparations \\
\hline \\
Corresponding Author: \\
Firzan Nainu \\
Fakultas Farmasi, Universitas \\
Hasanuddin \\
Makassar, 90245, \\
Indonesia \\
Phone: +62 411 588556 \\
Email: firzannainu@unhas.ac.id
\end{tabular}

Email: firzannainu@unhas.ac.id

\begin{abstract}
Vertebrates, including humans, are equipped with innate and adaptive immune systems that work together to protect the body from harmful materials, including various pathogens and cancer cells. Both immune systems routinely check various materials present in the body. One way used by the immune system in performing its duties is through activation of nucleic acid sensors that serve to provide information on the presence of foreign DNA or RNA or the possible existence of host DNA copies in the cytoplasm or other inappropriate locations. When pathogenic genomes are detected by these sensors, the effectors of immune system will be activated through a series of processes and culminated in the eradication of targeted nucleic acid or even induction of apoptosis in the corresponding cell. Some of nucleic acid sensors have been identified include Toll-like receptors (TLR), RIG-I-like receptors (RLRs), cyclic GMP-AMP synthase (cGAS), and interferon- $\gamma$-inducible protein 16 (IFI16). However, a number of pathogens develops various mechanisms to avoid these sensors so that infection can still occur. Thus, various studies to improve the knowledge on how nucleic acid sensors participate as an arm of intracellular immune responses as well as mechanisms for the development of pathogenic resistance to the detection of such sensors are essential to be encouraged. Such endeavours may provide new insights into the development of various pharmaceutical preparations such as vaccines and intracellular antimicrobials.
\end{abstract}

How to cite (APA 6th Style):

Usmar., Arfiansyah R., Nainu F. (2017). Sensor Asam Nukleat Sebagai Aktivator Imunitas Intrinsik Terhadap Patogen Intraseluler. Jurnal Farmasi Galenika (Galenika Journal of Pharmacy), 3(2), 174-190. doi: 10.22487/j24428744.2017.v3.i2.8922 


\begin{abstract}
ABSTRAK
Vertebrata, termasuk manusia, dilengkapi dengan sistem imun alamiah dan sistem imun adaptif yang saling bekerjasama untuk melindungi tubuh dari material berbahaya, termasuk berbagai patogen dan sel-sel kanker. Kedua sistem imun tersebut secara rutin melakukan pengecekan terhadap beragam material yang ada di dalam tubuh. Salah satu cara yang digunakan oleh sistem imun dalam melaksanakan tugasnya adalah melalui pengaktifan sensor asam nukleat yang berfungsi untuk memberikan informasi keberadaan DNA atau RNA asing maupun kemungkinan adanya salinan DNA inang di sitoplasma atau lokasi lain yang tidak semestinya. Ketika genom patogen terdeteksi oleh sensor-sensor tersebut, selanjutnya efektor sistem imun akan diaktivasi melalui serangkaian proses dan berakhir dengan eradikasi asam nukleat target atau bahkan induksi apoptosis sel yang bersangkutan. Beberapa sensor asam nukleat yang telah ditemukan antara lain adalah Toll-like receptor (TLR), RIGI-like receptors (RLRs), cyclic GMP-AMP synthase (cGAS), dan interferon- $\gamma$-inducibleprotein 16 (IFI16). Namun, sejumlah patogen telah memiliki mekanisme untuk menghindari sensor-sensor tersebut sehingga infeksi tetap dapat terjadi. Dengan demikian, berbagai penelitian untuk meningkatkan pengetahuan tentang bagaimana sensor asam nukleat bekerja sebagai salah satu respon imun intraseluler serta mekanisme terbentuknya resistensi patogen terhadap deteksi sensor tersebut sangat penting untuk didorong. Hal ini akan memberikan wawasan baru dalam pengembangan berbagai sediaan farmasi terkait seperti vaksin dan antimikroba intraseluler.
\end{abstract}

Kata Kunci : sensor DNA; sensor RNA; imunitas terhadap mikroba; resistensi terhadap sistem imun, sediaan farmasi

\section{PENDAHULUAN}

Setiap hari tubuh kita berinteraksi dengan berbagai objek yang cenderung menjadi tempat nyaman bagi bakteri, virus, jamur, maupun parasit berbahaya untuk bermukim. Berbagai mikroorganisme ini dapat menimbulkan penyakit dan seringkali hal ini berujung pada kematian(Medzhitov, 2007; Murphy, 2011). Pada tahun 2005, Indonesia dihebohkan oleh kasus infeksi flu burung yang disebabkan oleh virus H5N1, salah satu strain virus influenza tipe A yang sangat berbahaya. Pada skala global, virus H1N1 yang juga merupakan kerabat dekat virus H5N1, menelan sejumlah korban di Amerika pada tahun 2009. Selain itu, pada kurun tahun 2013 - 2016, virus Ebola menebarkan teror kematian di benua Afrika dengan jumlah kasus lebih dari 28 ribu dan hampir setengahnya berakhir dengan kematian(Coltart et al., 2017). Ketiga virus tersebut merupakan virus bergenom RNA dengan tingkat kematian yang cukup tinggi. Selain virus RNA, beberapa virus bergenom DNA seperti virus hepatitis B (HBV) dan berbagai jenis virus herpes (human herpesvirus, HHV 1-8) telah dilaporkan menyebabkan penyakit-penyakit tertentu pada manusia mulai dari infeksi ringan yang dapat ditangani melalui pengobatan antivirus hingga kanker yang sulit untuk disembuhkan (Mandell et al., 2010; Murphy, 2011).

Pertanyaan menarik yang timbul dalam forum-forum diskusi pakar imunologi dan ilmu-ilmu terkait lainnya adalah: mengapa infeksi virus tersebut tidak berakhir dengan kematian massal populasi manusia di daerah-daerah tempat virus tersebut berkembang? Atau dengan kata lain, mengapa virus tersebut tidak menyebabkan mortalitas 100\%? Salah satu bidang yang dapat menjelaskan fenomena ini adalah bidang imunologi. Dalam bidang imunologi, telah diketahui bahwa manusia dilengkapi dengan sistem imun komprehensif yang memiliki kemampuan adaptasi yang sangat baik dalam melindungi sel tubuh manusia dari serangan berbagai patogen (Medzhitov, 2007; Murphy, 2011). Manusia memiliki beragam komponen sistem imun alamiah (innate) mulai dari sederet komplemen yang dapat menyebabkan lisis pada bakteri hingga kehadiran sel natural killer (NK) yang bertugas memburu sel-sel yang terinfeksi oleh patogen intraseluler seperti virus (Medzhitov, 2007). Selain sistem imun alamiah, tubuh manusia juga dilengkapi dengan berbagai jenis pertahanan seluler adaptif (adaptive immunity) seperti sel limfosit $\mathrm{T}$ helper yang memiliki molekul pengenal berupa CD4 
dan sel limfosit $\mathrm{T}$ sitotoksik yang menggunakan antigen permukaan CD8 sebagai fasilitator untuk mengenali sel-sel yang terinfeksi virus. Selain respon yang diperantarai oleh aspek seluler, sistem imun adaptif juga memiliki beragam antibodi yang dapat menyerang dan memberikan tanda khusus (tagged) pada permukaan patogen, yang disebut opsonisasi, agar selanjutnya dihancurkan oleh sel-sel fagosit (Murphy, 2011).

Tujuan utama sistem imun di dalam tubuh manusia dan makhluk hidup lainnya adalah untuk mencegah replikasi patogen sehingga pada akhirnya mengurangi atau meredakan gejala yang timbul akibat infeksi. Untuk mendukung fungsi tersebut, tubuh manusia dilengkapi oleh berbagai sensor untuk mendeteksi keberadaan patogen. Salah satu sensor yang dimiliki oleh sel manusia adalah sensor asam nukleat yang bertugas untuk mendeteksi keberadaan asam nukleat asing (yang pada umumnya merupakan milik patogen) di dalam sitoplasma maupun nukleus (inti) sel (Chan \& Gack, 2016; Desmet \& Ishii, 2012). Dengan sensor-sensor tersebut, sistem imun intrinsik sel akan mampu mendeteksi keberadaan DNA atau RNA patogen dan sekaligus menanganinya sejak dini. Mengingat komponen penyusun DNA dan RNA manusia memiliki kemiripan yang sangat tinggi dengan komponen penyusun asam nukleat pada patogen, kunci keberhasilan pendeteksian terletak pada kemampuan sensor asam nukleat sel manusia untuk membedakan DNA atau RNA inang dari DNA atau RNA patogen. Dengan demikian, sistem imun yang mampu melakukan tugasnya dengan baik akan memberikan peluang yang tinggi kepada manusia untuk bertahan hidup. Namun, patogen pun memiliki kemampuan untuk beradaptasisehingga dapat bertahan hidup di tengah ancaman serangan sistem imun. Beberapa hasil penelitian terkini telah melaporkan bahwa patogen intraseluler memiliki sejumlah mekanisme tertentu untuk menghindari sensor asam nukleat inang (Chan \& Gack, 2016).

Dalam kondisi seperti itu, ancaman infeksi menjadi tak terhindarkan. Dengan demikian, perhatian khusus terkait hal ini menjadi sangat diperlukan. Apalagi dengan semakin banyaknya kasus infeksi akibat patogen intraseluler yang terjadi belakangan ini baik dalam skala global maupun dalam wilayah Indonesia. Beberapa kasus yang disebabkan oleh virus (Ebola, HIV, virus hepatitis, virus influenza tipe A, dan lain lain), bakteri intraseluler (Mycobacterium tuberculosis dan $M$. leprae) maupun parasit intraseluler (Toxoplasma gondii dan berbagai jenis Plasmodium) menjadi momok sangat meresahkan sebab belum dapat dieradikasi sepenuhnya (Mandell et al., 2010). Melalui artikel ini, kami berusaha merangkum kemajuan yang telah dicapai oleh para peneliti di bidang imunologi dan bidang lainnya mengenai respon sistem imun dalam mengenali dan memberikan reaksi terhadap asam nukleat patogen intraseluler. Bagaimana hal ini tercapai dan apa yang akan dilakukan oleh sistem imun intrinsik sel inang ketika asam nukleat patogen terdeteksi di dalam sel? Di dalam artikel ini, kami mengulas dan membahas beberapa hal penting yang sekiranya dapat meningkatkan wawasan peneliti Indonesia mengenai pentingnya topik ini dalam upaya penyediaan sediaan farmasi seperti vaksin dan antimikroba yang poten dalam pengobatan infeksi patogen intraseluler.

\section{PATOGEN INTRASELULER: DEFINISI DAN KLASIFIKASI}

Patogen didefinisikan sebagai mikroba yang dapat menyebabkan kerusakan pada inang (Casadevall \& Pirofski, 2002). Berdasarkan lokasi siklus hidupnya, patogen diklasifikasikan menjadi dua jenis yaitu patogen ekstraseluler dan patogen intraseluler (Silva, 2012). Berbeda dengan patogen ekstraseluler yang dapat hidup di luar sel, patogen intraseluler membutuhkan keberadaan sel inang untuk tumbuh dan bereproduksi di dalamnya (Casadevall, 2008; Casadevall \& Pirofski, 2002).

Patogen intraseluler terbagi ke dalam dua grup: obligat (obligate) dan fakultatif (facultative). Patogen obligat intraseluler tidak memiliki kemampuan untuk bereproduksi di luar sel inang. Semua virus dan beberapa bakteri seperti Rickettsia dan Chlamydia spp. serta protozoa seperti Plasmodium spp. termasuk ke dalam jenis ini. Sedikit berbeda dengan jenis obligat, patogen fakultatif intraseluler memiliki kemampuan untuk tumbuh di luar sel inang. Namun, pada kondisi tertentu dan sekaligus untuk menghindari respon imun ekstraseluler seperti komplemen dan antibodi, patogen jenis ini memilih untuk bereplikasi di dalam sel. Mycobacterium tuberculosis,Cryptococcus neoformans, dan Legionella pneumophila merupakan beberapa mikroba yang hidup secara fakultatif intraseluler (Casadevall \& Pirofski, 2002). 


\section{MENGAPA PATOGEN INI MASUK KE DALAM SEL?}

Patogen intraseluler dapat masuk ke dalam sel melalui proses endositosis (Bonazzi \& Cossart, 2006). Dengan masuk ke dalam sel, patogen dapat menghindari interaksi dengan berbagai molekul sistem imun seperti komplemen, sitokin, dan antibodi serta dapat menghindari ancaman fagositosis oleh fagosit profesional seperti makrofag (Casadevall, 2008; Medzhitov, 2007; Ploegh, 1998). Namun, beberapa hasil penelitian menunjukkan bahwa bakteri dan virus juga dapat masuk ke dalam sel target melalui proses fagositosis (Ribet \& Cossart, 2015). Langkah pertama yang dilakukan patogen adalah menginfeksi sel tertentu lalu selanjutnya menginduksi apoptosis pada sel tersebut. Peningkatan jumlah sel apoptotik (yang mengandung virus atau bakteri patogen) selanjutnya memicu makrofag untuk melakukan fagositosis terhadap sel-sel apoptotik tersebut. Ketika sel-sel apoptotik telah mengalami fagositosis dan masuk ke dalam kompartemen khusus di dalam makrofag, yang disebut fagosom, virus atau bakteri yang berada di dalam sel apoptotik tersebut akan keluar dari fagosom untuk selanjutnya masuk ke dalam lingkungan sitoplasma makrofag yang bersangkutan (Arandjelovic \& Ravichandran, 2015; Zamboni \& Rabinovitch, 2004). Melalui proses ini, bakteri atau virus tersebut dapat menginfeksi makrofag. Terlepas dari metode yang digunakan oleh patogen intraseluler untuk masuk ke dalam sel, gaya hidup ini tentunya mendorong patogen-patogen tersebut untuk mengembangkan mekanisme tertentu agar berhasil memasuki sel inang, bereplikasi di dalamnya, dan keluar dari sel yang terinfeksi tersebut untuk kemudian mencari sel-sel baru sebagai target selanjutnya.

\section{RESPON IMUN TERHADAP PATOGEN INTRASELULER}

Ketika patogen intraseluler masuk ke dalam tubuh, patogen akan melakukan replikasi untuk memperbanyak diri dan hal ini akan memicu aktivasi sistem imun intrinsik di dalam sel (Medzhitov, 2007). Sistem imun merupakan bagian khusus dari inang yang akan memberikan perlindungan terhadap ancaman patogen dengan cara mengeliminasi entitas patogen dan mencegah kerusakan yang timbul pada jaringan akibat aktivitas patogen (Takeuchi \& Akira, 2010). Respon imun alamiah (innate immune responses) merupakan bagian sistem imun yang akan segera aktif mencari patogen dan berusaha menetralisir ancaman yang timbul akibat keberadaan patogen tersebut di dalam tubuh (Medzhitov, 2007; Murphy, 2011). Sebagai kunci utama yang diperlukan untuk mengaktifkan rangkaian proses sistem imun, pengenalan patogen melalui berbagai komponen sistem imun alamiah (innate) menjadi sangat penting (Crozat et al., 2009; Desmet \& Ishii, 2012; Nainu et al., 2017). Pengenalan komponenkomponen patogen yang bersifat antigenik oleh berbagai sensor maupun reseptor terkait sistem imun dapat terjadi di luar maupun di dalam sel (Medzhitov, 2007; Takeuchi \& Akira, 2010).

Lazimnya, komponen humoral (misalnya komplemen) dan komponen seluler (misalnya sel fagosit dan sel NK) sistem imun alamiah akan menetralisir patogen ketika masih berada di lingkungan ekstrasel (Medzhitov, 2007). Namun, komponen-komponen respon imun tersebut tidak mampu memberikan perlindungan terhadap inang ketika patogen telah berhasil masuk ke dalam sel target (Medzhitov, 2007; Takeuchi \& Akira, 2010). Untungnya sel tubuh makhluk hidup, termasuk manusia, dilengkapi dengan berbagai macam sensor untuk mendeteksi keberadaan molekul-molekul asing (antigen), termasuk di antaranya adalah sensor asam nukleat yang berfungsi untuk mengidentifikasi keberadaan genom patogen di dalam sitoplasma sel inang (Broz \& Monack, 2013; Desmet \& Ishii, 2012). Dengan terdeteksinya asam nukleat (umumnya genom) dari patogen, maka sistem imun intrinsik sel pun menjadi aktif. Hal ini kemudian mendorong proses eliminasi asam nukleat asing tersebut dari lingkungan intraseluler yang kemudian berujung pada penghambatan replikasi genom patogen yang bersangkutan. Bila berkelanjutan, hal ini akan memicu kematian patogen (Broz \& Monack, 2013; Takeuchi \& Akira, 2010).

\section{SENSOR ASAM NUKLEAT}

Untuk mengenali patogen, sistem imun menggunakan beberapa cara unik. Salah satunya adalah dengan menggunakan berbagai pattern recognition receptors (PRRs) (Takeuchi \& Akira, 2010). Konsep PRRs dikemukakan pertama kalinya oleh Charles Janeway (Janeway, 1989). Janeway mengusulkan bahwa patogen memiliki molekul penanda yang disebut pathogen-associated molecular patterns (PAMPs). Molekul penanda ini akan dikenali oleh PRRs untuk selanjutnya menginduksi ekspresi gen tertentu yang 
terkait dengan imunitas (Janeway, 1989; Medzhitov, PAMPs yang dikenalinya terangkum dalam Tabel 1. 2009). Beberapa contoh PRRs dan molekul ligan

Tabel 1. Daftar pathogen recognition receptors (PRRs)beserta ligan pathogen-associated molecular patterns (PAMPs) yang dikenali oleh PRRs terkait.

\begin{tabular}{|c|c|c|c|}
\hline PRRs & Lokalisasi & $\begin{array}{l}\text { Ligan PAMPs yang } \\
\text { dikenali }\end{array}$ & Sumber ligan \\
\hline \multicolumn{4}{|c|}{ PRR membran } \\
\hline \multicolumn{4}{|c|}{ TLR } \\
\hline TLR1 & Membran plasma & Triasil lipoprotein & Bakteri \\
\hline TLR2 & Membran plasma & Lipoprotein & $\begin{array}{l}\text { Bakteri, virus, } \\
\text { parasit, diri } \\
\text { sendiri (self) }\end{array}$ \\
\hline TLR3 & Endolisosom & dsRNA & Virus \\
\hline TLR4 & Membran plasma & Lipopolisakarida (LPS & $\begin{array}{l}\text { Bakteri, virus, } \\
\text { diri sendiri }\end{array}$ \\
\hline TLR5 & Membran plasma & Flagellin & Bakteri \\
\hline TLR6 & Membran plasma & Diasil lipoprotein & Bakteri dan virus \\
\hline TLR7 & Endolisosom & ssRNA & $\begin{array}{l}\text { Virus, bakteri, } \\
\text { diri sendiri }\end{array}$ \\
\hline TLR8 & Endolisosom & ssRNA & $\begin{array}{l}\text { Virus, bakteri, } \\
\text { diri sendiri }\end{array}$ \\
\hline TLR9 & Endolisosom & CpG DNA & $\begin{array}{l}\text { Virus, bakteri, } \\
\text { protozoa, diri } \\
\text { sendiri }\end{array}$ \\
\hline TLR10 & Endolisosom & Belum diketahui & Belum diketahui \\
\hline TLR11 & Membran plasma & Molekul mirip profilin & Protozoa \\
\hline TLR12 & Endolisosom & Profilin & Parasit \\
\hline TLR13 & Endolisosom & rRNA & Bakteri \\
\hline \multicolumn{4}{|l|}{ CLR } \\
\hline Dectin-1 & Membran plasma & $\beta$-glukan & Kapang \\
\hline Dectin-2 & Membran plasma & $\beta$-glukan & Kapang \\
\hline MINCLE & Membran plasma & SAP130 & $\begin{array}{l}\text { Diri sendiri, } \\
\text { kapang }\end{array}$ \\
\hline \multicolumn{4}{|c|}{ PRR sitoplasma } \\
\hline \multicolumn{4}{|c|}{ RLR } \\
\hline RIG-I & Sitoplasma & $\begin{array}{l}\text { dsRNA pendek; 5'- } \\
\text { trifosfat dsRNA }\end{array}$ & $\begin{array}{l}\text { Virus RNA, virus } \\
\text { DNA }\end{array}$ \\
\hline MDA-5 & Sitoplasma & dsRNA panjang & $\begin{array}{l}\text { Virus RNA } \\
\text { (Picornaviridae) }\end{array}$ \\
\hline LGP2 & Sitoplasma & Belum diketahui & Virus RNA \\
\hline \multicolumn{4}{|l|}{ NLR } \\
\hline NOD1 & Sitoplasma & iE-DAP & Bakteri \\
\hline NOD2 & Sitoplasma & MDP & Bakteri \\
\hline
\end{tabular}


Ketika patogen intraseluler telah masuk ke dalam sel, perlindungan akan diberikan oleh imunitas intrinsik melalui partisipasi sejumlah sensor intrasel (Schlee \& Hartmann, 2016; Takeuchi \& Akira, 2010). Seperti yang terlihat pada Tabel 1, beberapa PRR yang dimiliki oleh sistem imun alamiah manusia bertugas mendeteksi asam nukleat patogen. Beberapa jenis reseptor ataupun sensor yang akan mengaktifkan respon imun alamiah yang berfungsi untuk mendeteksi dan melenyapkan ancaman asam nukleat asing adalah Toll-like receptors (TLRs), RIG-I-like receptors (RLRs), Cyclic GMP-AMP synthase (cGAS), dan Interferon- $\gamma(I F N \gamma)$-inducible protein 16 (IFI16) (Broz \& Monack, 2013; Chan \& Gack, 2016). Sebagai tambahan, peran sistem RNA interference juga turut membantu tubuh dalam memerangi keberadaan patogen intraseluler (Ding, 2010).

Asam nukleat adalah makromolekul kompleks yang tersusun atas rantai nukleotida yang menyimpan informasi genetik dari suatu makhluk hidup (Alberts et al., 2014). Asam deoksiribonukleat (deoxyribonucleic acid, DNA) dan asam ribonukleat (ribonucleic acid, RNA) merupakan dua jenis asam nukleat yang dimiliki oleh makhluk hidup. Secara umum, DNA merupakan material genetik yang terletak di dalam inti sel manusia dan makhluk hidup lainnya, termasuk bakteri. Akan tetapi, berbeda dengan spesies metazoan lainnya, sejumlah besar virus justru menggunakan RNA sebagai genomnya (Alberts et al., 2014; Wagner et al., 2007). Contoh virus RNA yang terkenal adalah virus influenza, virus hepatitis $\mathrm{C}$, human immunodeficiency virus (HIV), dan virus dengue. Namun demikian, beberapa virus seperti virus herpes dan virus hepatitis B memiliki genom yang tersusun dari DNA (Wagner et al., 2007).

Genom manusia dan eukariot lainnya tersusun dari berbagai gen yang dipaketkan dalam bentuk dua untai DNA (double stranded DNA, dsDNA). Bakteri sebagai contoh makhluk hidup prokariotik juga memiliki genom dalam bentuk dsDNA. Akan tetapi, selain dsDNA, adapula struktur single stranded DNA (ssDNA) yang saat ini telah diketahui merupakan bentuk genom dari virus-virus dalam famili Parvoviridae (termasuk di dalamnya adalah Parvovirus B19 yang menginfeksi manusia dan menyebabkan gangguan berupa erythema infectiosum) (Mandell et al., 2010; Wagner et al., 2007).
Manusia dan eukariot lainnya menggunakan DNA untuk menghasilkan RNA melalui proses transkripsi. Selanjutnya, melalui serangkaian proses, RNA akan dimodifikasi menjadi messenger RNA (mRNA) untuk kemudian digunakan sebagai cetakan (template) untuk memproduksi makromolekul protein menggunakan kompleks ribosom (Alberts et al., 2014). Protein tersebut akan digunakan oleh sel untuk berbagai proses dalam upaya untuk menjaga homeostasis, termasuk di antaranya adalah sebagai enzim untuk mengolah substrat tertentu atau sebagai reseptor untuk menerima sinyal dari suatu ligan, yang bermanfaat untuk kelangsungan hidup sel tersebut (Alberts et al., 2014). Mengingat bahwa manusia dan makhluk hidup lain sangat tergantung pada DNA genom dan RNA dalam menjaga homeostasis berbagai proses biologis, upaya untuk membedakan DNA dan/atau RNA milik sendiri (self) dengan DNA dan/atau RNA asing (non-self) milik patogen menjadi sangat penting untuk dilakukan. Kegagalan sistematik dalam proses diskriminasi asam nukleat tersebut telah dilaporkan berujung pada timbulnya berbagai jenis penyakit autoimun (Takeuchi \& Akira, 2010).

\section{RAGAM SENSOR ASAM NUKLEAT}

\section{a. Toll-like receptors (TLRs)}

Reseptor Toll (Toll receptor)beserta komponen dan jalur sinyalnyapertama kali ditemukan pada lalat buah Drosophila melanogaster melalui sistem skrining genetik yang dikembangkan oleh tim peneliti dari Jerman (Nusslein-Volhard \& Wieschaus, 1980). Pada saat itu, reseptor Toll diketahui berperan penting dalam proses segmentasi dan tumbuhkembang embrio Drosophila. Namun, 16 tahun setelahnya, reseptor Toll dilaporkan memiliki fungsi penting dalam imunitas alamiah $D$. melanogaster(Lemaitre et al., 1996). Setahun kemudian, sebuah homolog reseptor Toll yang memiliki peran penting dalam sistem imun manusia, diidentifikasi oleh grup Charles Janeway (Medzhitov et al., 1997) dan disusul oleh penemuan lima TLR lainnya, pada tahun selanjutnya(Rock et al., 1998).

Toll-like receptors (TLRs) merupakan satu dari beberapa PRRs yang telah dikarakterisasi secara komprehensif dan merupakan kelompok reseptor 
yang bertanggungjawab dalam mendeteksi patogen baik di dalam dan di luar sel (Akira et al. 2006). TLRs ditandai oleh ciri umum berupa $N$-terminal leucinerepeats (LRRs) dan sebuah daerah transmembran yang diikuti oleh domain Toll/IL-1R (TIR) pada daerah sitoplasma. Tiap TLR mengenali PAMP maupun komponen self-antigen yang berbeda (Tabel 1). Saat ini, sembilan jenis reseptor Toll (Toll1-Tol19) telah ditemukan pada $D$. melanogaster(Valanne et al., 2011), 10 jenis TLRs (TLR1-TLR10) pada manusia, dan 12 jenis TLRs (TLR1-TLR9 dan TLR11-TLR13) pada mencit (Kawasaki \& Kawai, 2014; Takeuchi \& Akira, 2010). Hal ini mengukuhkan TLRs sebagai salah satu famili reseptor yang lestari pada makhluk hidup. Berdasarkan hal tersebut, penelitian-penelitian dasar menggunakan hewan model invertebrata seperti lalat buah $D$. melanogaster dapat mengungkap beragam informasi penting terkait TLRs pada tingkat seluler dan molekuler yang kemungkinan pula terjadi pada hewan tingkat tinggi, termasuk manusia.

Khusus untuk Toll-like receptors, TLR3, TLR7, TLR8 dan TLR9 pada mamalia berfungsi sebagai sensor asam nukleat bakteri, virus, maupun parasit. TLR3, TL7, dan TLR8 bertugas mengenali RNA dan TLR9 mengenali CpG-DNA (Takeuchi \& Akira, 2010). TLR3 terlokalisasi di endosom dan bertugas dapat mengenali RNA untai ganda (double-stranded RNA, dsRNA) yang telah disinyalir sebagai komponen genom virus. Melalui elusidasi struktur kristal TLR3, diketahui bahwa dsRNA terikat pada daerah $\mathrm{N}$-terminal dan C-terminal dari TLR3 dan ikatan ini mengakibatkan dimerisasi dua molekul TLR3 (Choe et al. 2005, Liu et al. 2008). TLR7 (mencit) dan TLR7/TLR8 (manusia) terletak di endosom dan berfungsi untuk mengenali RNA untai tunggal (single-stranded RNA, ssRNA) berbagai virus dan senyawa analog purin seperti imidazoquinolin (Takeuchi \& Akira, 2010). Berbeda dengan TLR lainnya, TLR9 mengenali DNA yang tidak termetilasi dan mengandung motif $\mathrm{CpG}$ yang umumnya dimiliki oleh bakteri dan virus. Aktivasi TLR9 juga dapat disebabkan oleh rantai gula inti DNA 2'-deoksiribosa (Haas et al., 2008).

Seperti yang terlihat pada Tabel 1, sensor asam nukleat TLRs terlokalisasi di dalam kompartemen tertutup (seperti misalnya endosom). Hal ini sangat penting untuk menghindari aktivasi kelompok TLR tersebut oleh asam nukleat inang (host), baik DNA nukleus maupun mRNA inang yang umumnya banyak terdapat di daerah sitoplasma. Kegagalan untuk mencegah aktivasi sensor asam nukleat TLR oleh self-DNA maupun self-RNA telah dilaporkan memicu proses autoimunitas (Barton \& Kagan, 2009).

Pengenalan PAMPs oleh TLRs akanmemicu peningkatan ekspresi gen-gen tertentu terkait imunitas. Walaupun jenis gen target sangat bergantung pada tipe TLR dan jenis sel tempat proses tersebut terjadi, secara umum jalur sinyal (signaling pathway) penyampaian pesan antara TLRs dan gen target hanya terbagi menjadi dua jenis: melalui perantaraan MyD88 dan TRIF (Takeuchi \& Akira, 2010). Aktivasi TLR3 oleh dsRNA akan dilanjutkan melalui jalur sinyal TRIF sedangkan aktivasi TLR7 dan TLR8 oleh ssRNA, TLR9 oleh CpG-DNA, dan TLR13 oleh rRNA akan dilanjutkan melalui jalur sinyal MyD88 (Gambar 1). Walaupun diproses dengan jalur sinyal yang berbeda, aktivasi TLRs akan bermuara pada ekspresi gen-gen terkait produksi interferon (IFN) tipe 1 dan berbagai jenis sitokin proinflamasi (Takeuchi \& Akira, 2010). Dengan demikian, pengenalan asam nukleat patogen oleh TLRs merupakan salah satu bentuk imunitas alamiah yang sangat penting bagi setiap makhluk hidup. Namun perlu untuk dipahami bahwa aktivasi TLR memerlukan pengaturan yang sangat ketat untuk menghindari timbulnya reaksi autoimun. 


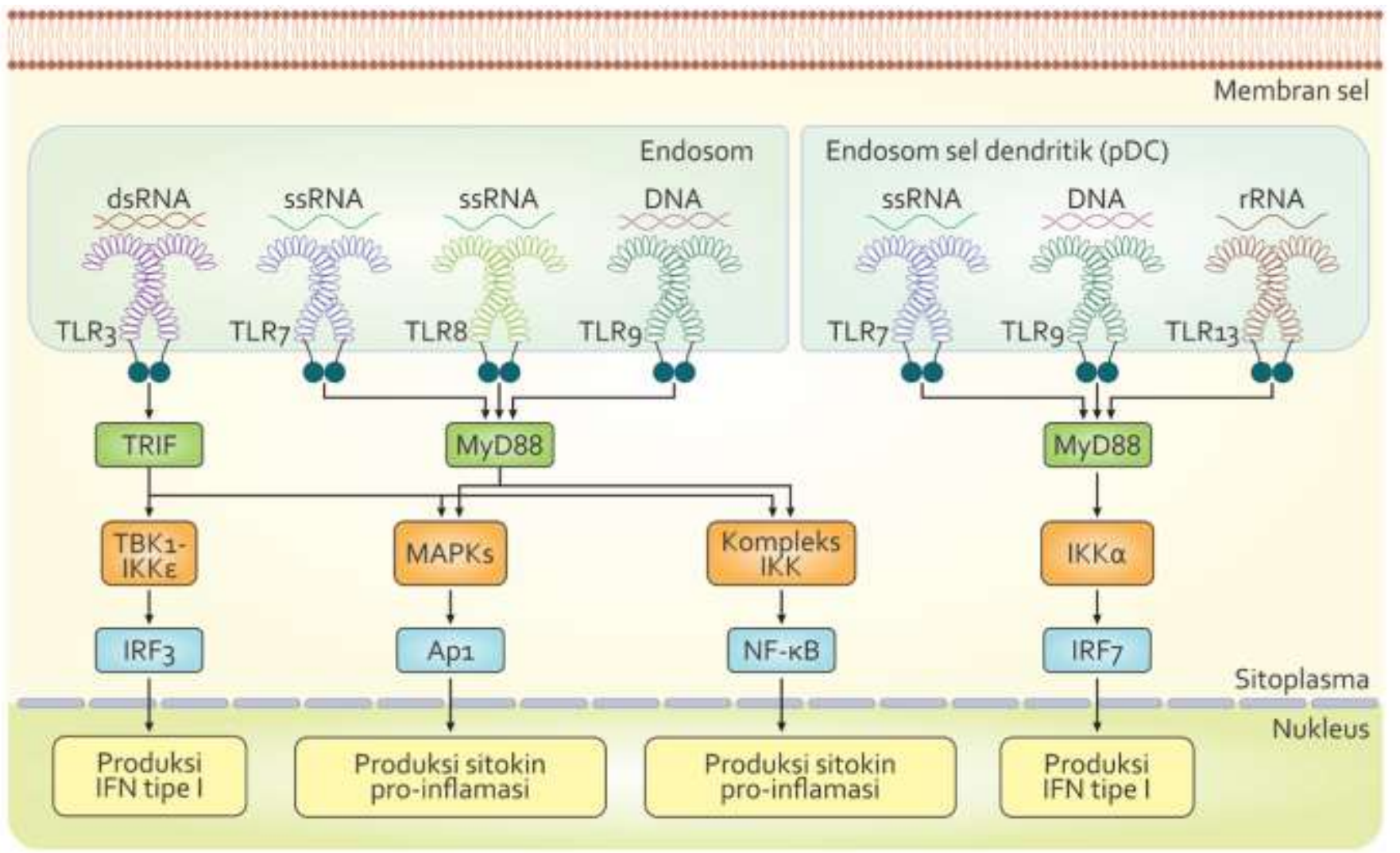

Gambar 1. Jalur sinyalToll-like receptors (TLRs) beserta jenis asam nukleat yang dikenalinya. TLR9 adalah satu-satunya TLR yang mengenali ligan DNA sedangkan empat TLR lainnya, TLR3, TLR7, TLR8, dan TLR13 mengenali ligan RNA. Sinyal dimulai ketika TLR mengenali ligan terkait dan mengaktifkan salah satu dari dua jalur: TRIF atau MyD88. Aktivasi TRIF maupun MyD88 di daerah sitoplasma dilanjutkan dengan ekspresi IFN tipe 1 ataupun produksi berbagai sitokin proinflamasi yang digunakan sebagai respon imun terhadap patogen.

ssRNA = single stranded RNA, dsRNA=double stranded RNA, rRNA=ribosomal RNA, TLR = Toll-like receptor, TRIF=TIR-domain-containing adapter-inducing interferon- $\beta$, MyD88 =Myeloid differentiation primary response 88 , TBK1 $=$ TANK-binding kinase $1, \mathrm{IKK}=I \kappa B$ kinase, $\mathrm{IRF}=$ Interferon regulatory transcription factor, $\mathrm{MAPK}=$ Mitogen-activated protein kinase, $\mathrm{Ap} 1=$ Activator protein $1, \mathrm{NF}-\mathrm{kB}=$ Nuclear factor kappa-light-chain-enhancer of activated $B$ cells, IFN = Interferon.

\section{b. RIG-I-like receptors (RLRs)}

Famili RIG-I-like receptor (RLR)merupakan kelompok sensor RNA yang terdiri atas retinoic acidinducible gene-I protein (RIG-I), melanoma differentiation-associated gene 5 (MDA5), and LGP2 (Chan \& Gack, 2016; Takeuchi \& Akira, 2010). RIGI dan MDA5 tersusun atas empat modul yaitu dua $N$ terminal caspase recruitment domains (CARDs), sebuah centralDEAD box helicase/ATPase domain, dan sebuah C-terminal regulatory domain. LGP2, anggota famili RLR yang lain, memiliki semua komponen tersebut kecuali modul CARDs (Takeuchi \& Akira, 2010). Keberadaan modul CARDs pada
RIG-I dan MDA5 memungkinkan kedua RLR tersebut untuk menginisiasi sinyal sistem imun alamiah sesegera mungkin setelah pengenalan RNA virus (Chan and Gack, 2016). Ekspresi RLRs akan ditingkatkan secara signifikan sebagai respon terhadap stimulasi IFN tipe-1 atau infeksi virus (Takeuchi \& Akira, 2010).

RLRs terlokalisasi di sitoplasma dan berfungsi untuk mengenali genom ssRNA dan dsRNA virus. Selain itu, dsRNA yang terbentuk sebagai bahan intermediat replikasi genom ssRNA virus, juga dikenali oleh sensor-sensor RLRs (Takeuchi \& Akira, 2010). Seperti yang terlihat pada Gambar 2, RIG-I sangat 
reaktif terhadap dsRNA pendek (dengan panjang hingga $1 \mathrm{~kb}$ ) dan keberadaan ujung 5 ' trifosfat pada ligan RNA yang dikenali oleh RIG-I akan meningkatkan aktivitas RIG-I dalam menginduksi produksi IFN tipe-1 (Takeuchi \& Akira, 2010). Walaupun demikian, ujung 5' trifosfat bukanlah merupakan suatu komponen yang harus dimiliki oleh ligan RNA. Baik ujung 5' monofosfat maupun RNA tanpa ujung 5' fosfat telah dilaporkan dapat menginduksi produksi IFN tipe-1 melalui RIG-I (Kato et al., 2008; Takahasi et al., 2008).

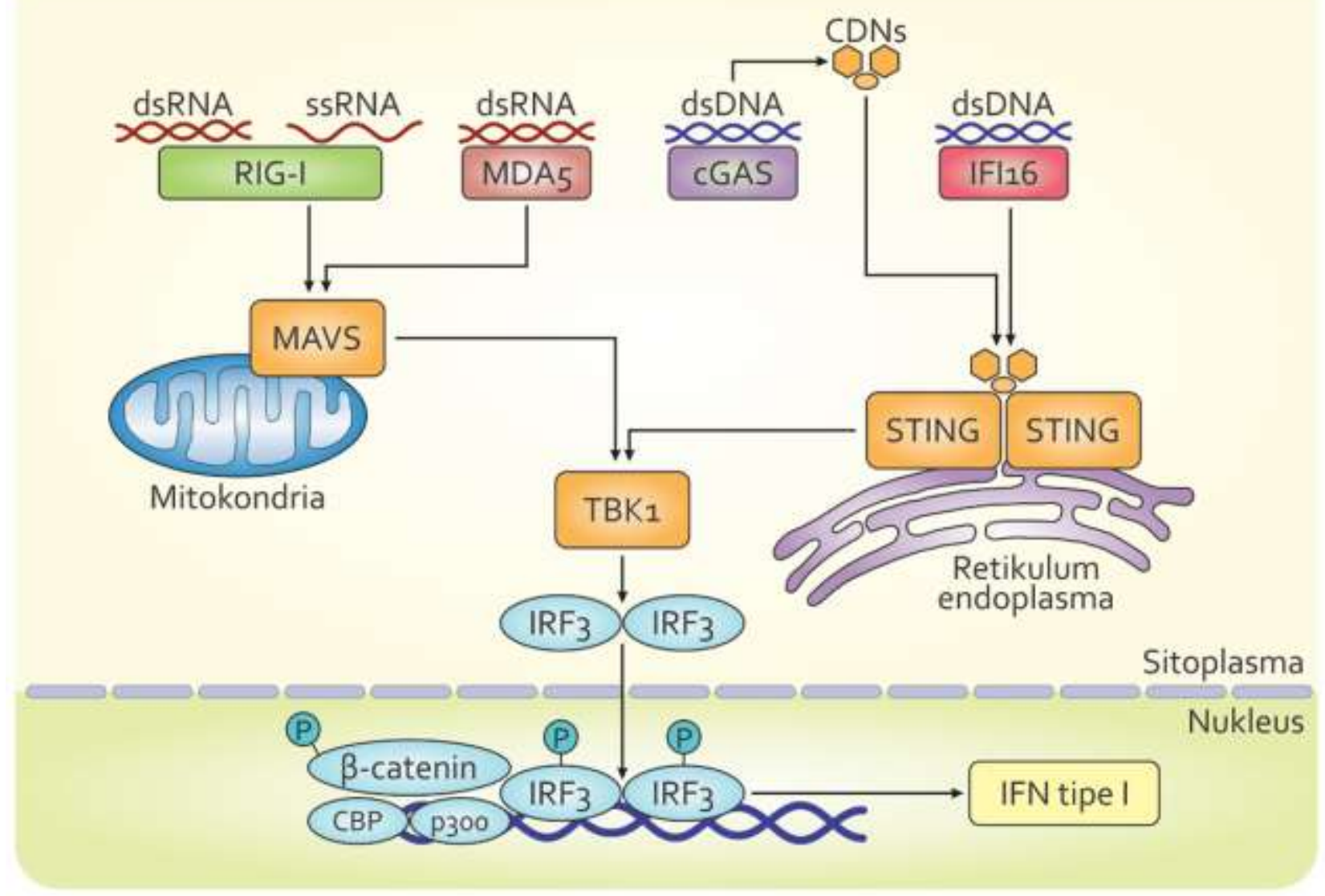

Gambar 2. Jalur sinyal RIG-I, MDA5, cGAS, dan IFI16 beserta jenis asam nukleat yang dikenali oleh masing-masing sensor. RIG-I dan MDA5 adalah sensor RNA sedangkan cGAS dan IFI16 merupakan sensor DNA. Fungsi efektor RIG-I dan MDA5 diperantarai oleh MAVS sedangkan cGAS dan IFI16 berinteraksi dengan STING baik langsung (IFI16) maupun tidak langsung (cGAS). MAVS atau STING kemudian mengaktivasi TBK1 yang selanjutnya menginduksi translokasi IRF3 dari sitoplasma ke nukleus untuk bersama-sama dengan beberapa DNA-binding proteinlainnya menginduksi ekspresi IFN tipe 1 sebagai respon pertahanan tubuh terhadap patogen intraseluler.

ssRNA = single stranded RNA, dsRNA = double stranded RNA, dsDNA =double stranded DNA, RIG-I =retinoic acidinducible gene-I protein, MDA5= melanoma differentiation-associated gene 5, MAVS = mitochondrial antiviral signaling, cGAS =cyclic GMP-AMP synthase, IFI16 =Interferon- $\gamma($ IFN $\gamma)$-inducible protein 16, CDNs =cyclic dinucleotides, STING = stimulator of interferon genes, TBK1 = TANK-binding kinase 1 , IRF $=$ Interferon regulatory transcription factor, $\mathrm{CBP}=$ CREB-binding protein

MDA5 bertugas mendeteksi dsRNA panjang (dengan ukuran $>2 \mathrm{~kb}$ ). RNA dengan struktur kompleks yang mengandung dsRNA maupun ssRNA dapat menginduksi aktivasi MDA5. Tetapi, dsRNA sederhana hasil intermediat replikasi genom ssRNA virus bukan merupakan ligan MDA5 (Pichlmair et al., 2009). Secara umum, RIG-I dan MDA5 berada dalam keadaan inaktif (auto-repressed)di dalam sel 
sehat. Hal ini tercapai melalui fosforilasi residu serin dan treonin pada modul CARDs dan pada $C$-terminal regulatory domain. Ketika virus RNA masuk ke dalam sel, genom RNA virus tersebut akan mengaktivasi perubahan konformasi RIG-I dan MDA5 untuk menjadi aktif (Kowalinski et al. 2011). Namun perlu dipahami bahwa seperti yang telah disebutkan di atas, aktivasi RIG-I maupun MDA5 sesuai dengan tipe RNA virus yang dikenali.

Berbeda halnya dengan RIG-I dan MDA5, LGP2 tidak memiliki modul CARDs sehingga tidak memiliki kemampuan untuk menginduksi IFN tipe-1. Walaupun demikian, LGP2 diketahui berfungsi sebagai pengendali negatif (negative regulator) respon RIG-I dan MDA5 dengan cara menghambat perubahan konformasi RLR atau dengan cara mencegah pengenalan ligan dsRNA oleh RIG-I dan MDA (Takeuchi \& Akira, 2010).

\section{c. Cyclic GMP-AMP synthase (cGAS)}

Setelah IFN tipe-1 ditemukan, sejumlah tim riset dari berbagai belahan dunia mulai melaporkan bahwa dsRNA dapat menginduksi produksi IFN tipe-1 melalui berbagai sensor RNA di dalam sel. Hingga kini, sistem imun intrinsik yang diperantarai oleh interferon jenis ini dipercaya sebagai sistem imun yang sangat ampuh karena dapat mengenali genom ssRNA dan genom dsRNA virus, sebuah tipe RNA yang tidak lazim terdapat di dalam sel mamalia (Hornung \& Latz, 2010).

Pertanyaan mengenai apakah sel mamalia dapat mengenali genom dsDNA bakteri dan virus dan membedakannya dengan genom dsDNA milik sendiri kurang begitu terdengar hingga tim peneliti dari Jepang menemukan bahwa DNA dalam fraksi kaya asam nukleat yang diperoleh dari lisat Mycobacterium bovis dapat menginduksi aktivasi efektor sistem imun (Tokunaga et al., 1984).Sejak saat itu, arah penelitian di bidang imunologi mulai merambah ke arah sensor DNA sistem imun. Tujuannya untuk mengetahui sensor DNA apakah yang digunakan oleh makhluk hidup eukariot untuk menemukenali dsDNA patogen dan menemukan mekanisme bagaimana sensor-sensor DNA tersebut membedakan dsDNA patogen dari dsDNA milik sendiri.

Penemuan TLR9 dan CpG-DNA sebagai ligannya membuka era baru sensor DNA sel. Keberadaan motif CpG dalam jumlah besar pada dsDNA bakteri tetapi hanya dalam jumlah yang sangat kecil pada DNA mamalia (Hornung \& Latz, 2010) memberikan indikasi yang sangat nyata bahwa sensor DNA memiliki kemampuan spesifik untuk membedakan dsDNA patogen dari dsDNA inang.Secara umum, sensor DNA sel dapat mengenali dsDNA milik sendiri. Namun, lokasi dsDNA eukariot yang berada di dalam nukleus mencegah aktivasi sensor DNA, yang pada umumnya berada di dalam sitoplasma ataupun kompartemen tertentu seperti endosom (Paludan \& Bowie, 2013).Akan tetapi, pada kondisi tertentu seperti kasus defisiensi deoksiribonukleaseII, dsDNA genom dari sel apoptotik yang seharusnya dicerna oleh deoksiribonuklease-II di dalam endosom sel fagosit terlepas ke sitoplasma dan dikenali oleh sensor DNA fagosit yang pada akhirnya memicu reaksi autoimun (Hornung \& Latz, 2010; Paludan \& Bowie, 2013).

Beberapa sensor DNA intrasel telah ditemukan, dikarakterisasi, dan dijelaskan secara rinci di dalam beberapa artikel review (Dempsey \& Bowie, 2015; Hornung \& Latz, 2010; Paludan \& Bowie, 2013). Salah satu sensor DNA yang saat ini mendapat perhatian luas dari para peneliti adalah cyclic GMPAMP synthase (cGAS). Enzim cGAS yang merupakan bagian dari famili nucleotydiltransferase adalah salah satu sensor yang dapat mendeteksi dsDNA berbagai virus (Sun et al., 2013). Pada umumnya sensor DNA intrasel, termasuk cGAS, berinteraksi dengan protein adaptor stimulator of interferon genes (STING) untuk menginduksi ekspresi IFN tipe-1 (Chan \& Gack, 2016). Untuk menggambarkan jalur sinyal hasil interaksi cGAS dan STING, istilah cGAS-STING pun digunakan dalam berbagai literatur.

Mekanisme sistem cGAS-STING dimulai dari pengenalan cGAS terhadap dsDNA virus yang 
selanjutnya menginduksi produksi cyclic dinucleotide cyclic GMP-AMP (cGAMP) sebagai second messenger. Molekul cGAMP kemudian berikatan dengan STING pada sel yang menghasilkannya dan sekaligus pula menyebar ke sel-sel tetangga yang belum terinfeksi oleh virus melalui gap junctions untuk berinteraksi dengan STING pada sel-sel tetangga tersebut. Interaksi cGAS dan STING akan memicu produksi IFN, kemokin, dan berbagai mediator pro-inflamasi yang digunakan sebagai penanda lokasi tempat antigen asing berada (Chan \& Gack, 2016; Paludan \& Bowie, 2013).

\section{d. Interferon- $\gamma$ (IFN $\gamma)$-inducible protein 16 (IFI16)}

Salah satu sensor DNA yang dapat berinteraksi dengan STING adalah Interferon- $\gamma(I F N \gamma)$-inducible protein 16 (IFI16) (Chan \& Gack, 2016). IFI16 merupakan salah satu protein yang termasuk ke dalam pyrin and HIN200 domain-containing protein family (PYHIN protein family) (Unterholzner et al., 2010). Berbeda dengan cGAS yang menggunakan perantara second messenger cGAMP untuk berinteraksi dengan STING, IFI16 berinteraksi secara langsung dengan STING sesaat setelah IFI16 mendeteksi keberadaan dsDNA di dalam daerah sitoplasma maupun di daerah nukleus (Chan \& Gack, 2016).

Hasil interaksi IFI16 dan STING akan mengaktifkan produksi interferon dan berbagai sitokin proinflamasi melalui jalur sinyal yang diperantarai oleh interferon regulatory factor 3 (IRF3) dan NF- $\mathrm{BB}$ (Chan \& Gack, 2016). Selain itu, IFI16 dapat mengaktivasi inflammasome, yang terbentuk dari aktivitas caspase 1 dan IL-1 $\beta$ (Jin et al., 2012). Berbeda dengan sensor DNA lainnya, IFI16 telah dilaporkan dapat mengenali keberadaan dsDNA herpes simplex virus 1 (HSV-1) dan Kaposi sarcomaassociated herpesvirus (KSHV, HHV8) di dalam nukleus (Orzalli et al., 2012), mengindikasikan bahwa IFI16 memiliki mekanisme untuk membedakan dsDNA virus dari dsDNA inang. Penelitian lanjutan sangat diperlukan untuk menemukan mekanisme tersebut.

\section{e. RNA interference (RNAi)}

Berbagai sensor RNA dan DNA yang telah dipaparkan di atas merupakan komponen utama dari hewan tingkat tinggi seperti mamalia. Sayangnya, sensor-sensor asam nukleat tersebut tidak tersedia secara komprehensif pada hewan-hewan invertebrata. Padahal, invertebrata seperti nematoda Caenorrhabditis elegans, lalat buah Drosophila melanogaster, dan lebah madu Apis mellifera juga dapat terinfeksi oleh berbagai jenis patogen baik berupa bakteri maupun virus (Brutscher \& Flenniken, 2015; Félix et al., 2011; Nainu et al., 2015; Panayidou et al., 2014; Xu \& Cherry, 2014). Pertanyaan yang timbul selanjutnya adalah bagaimana hewan-hewan invertebrata tersebut mengenali genom patogen dan membedakannya dari genom miliknya sendiri?

Salah satu cara yang digunakan oleh invertebrata untuk mengenali asam nukleat patogen adalah melalui mekanisme yang disebut RNA interference (RNAi). Konsep RNA interference (RNAi) mulai dipopulerkan setelah tim Andrew Fire dan Craig Mello membuktikan keberadaan RNAi pada nematoda C. elegans(Fire et al., 1998). Berkat penemuan tersebut, keduanya dianugerahi Nobel Prize pada tahun 2006. Keberadaan sistem RNAi juga telah dilaporkan pada lalat buah $D$. melanogaster (Kennerdell \& Carthew, 1998) dan belum lama ini pada mamalia (Maillard et al., 2013). Komponen RNAi yang paling penting untuk diketahui adalah Dicer dan Argonaute (Ding, 2010). Namun, artikel ini tidak ditulis untuk mengakomodir pembahasan mengenai RNAi. Bagi yang tertarik untuk mendalami, penjelasan lebih detail dapat ditemukan dalam artikel-artikel berikut (Agrawal et al., 2003; Ding, 2010; Siomi \& Siomi, 2009).

\section{RESPON PATOGEN TERHADAP SENSOR ASAM NUKLEAT}

Setiap patogen yang berhasil menginfeksi inangnya tentunya memiliki kemampuan untuk mencegah aktivasi sistem imun maupun menghindari serangan sistem imun. Dalam Review ini, kami akanmembahassecara ringkas mengenai mekanisme 
patogen dalam menghambat aktivasi sensor asam nukleat.

\section{a. Patogen memodifikasi lokasi replikasi atau struktur ligan RNA/DNA yang dikenali oleh sensor asam nukleat}

Virus memulai siklus hidupnya ketika asam nukleat genomnya, yang dapat berupa DNA atau RNA, masuk ke dalam sel inang. Asam nukleat genom virus tersebut akan bersirkulasi di dalam sitoplasma sebelum akhirnya menuju ke lokasi ideal replikasi, pada umumnya di sitoplasma untuk virus RNA, dan inti sel untuk virus DNA (Wagner et al., 2007). Ketika berada di dalam sitoplasma, asam nukleat virus tersebut akan berpotensi dikenali sebagai ligan oleh berbagai jenis PRR seperti TLR, RLR, cGAS, dan IFI16 (Chan \& Gack, 2016).

Untuk menghindari pengenalan oleh PRR tersebut, virus RNA memiliki kemampuan untuk menginduksi pembentukan kompartemen spesifik yang diselubungi oleh membran seluler di dalam sitoplasma atau dengan cara melakukan replikasi di dalam organel sel tertentu seperti retikulum endoplasma, aparatus Golgi, dan mitokondria (Chan \& Gack, 2016). Misalnya, virus dengue DENV, flavivirus penyebab demam berdarah dengue pada manusia, bereplikasi di dalam retikulum endoplasma yang secara efisien dapat melindungi dsRNA DENV dari deteksi RLR yang berada di sitoplasma (Uchida et al., 2014).

Berbeda dengan DENV, virus influenza tipe A (IAV) yang memiliki genom berupa delapan segmen RNA dapat melakukan replikasi di dalam nukleus untuk menghindari deteksi oleh TLR dan RLR. Beberapa strain IAV bahkan memiliki mekanisme untuk mencegah pengenalan RIG-I terhadap genom RNA virus di lingkungan sitoplasma. Mekanisme tersebut diperantarai oleh keberadaan subunit PB2 dari polimerase virus. Subunit PB2 memiliki afinitas yang tinggi pada nucleoprotein (NP) dan interaksi PB2 dan NP akan melindungi genom RNA virus dari deteksi RIG-I (Weber et al., 2015).

Mekanisme lain diperlihatkan oleh HIV, yang merupakan bagian dari retrovirus penyebab AIDS. Virus ini merupakan virus RNA namun dengan bantuan enzim reverse transriptase, HIVdapat membentuk genom cDNA yang kemudian diintegrasikan ke dalam genom dsDNA manusia. Genom cDNA ini telah dilaporkan berpotensi untuk terdeteksi oleh sensor DNA seperti cGAS (Gao et al., 2013). Namun, beberapa penelitian telah melaporkan bahwa HIV dapat mencegah aktivasi cGAS melalui dua acara: mengurangi produksi genom cDNA HIV menggunakan 3'-repair exonuclease 1 (TREX1) inang (Yan et al., 2010) dan melalui rekrutmen protein seluler cyclophillin A (CYPA) (Lahaye et al., 2013; Rasaiyaah et al., 2013). Namun, mekanisme CYPA dalam mencegah aktivasi cGAS hingga kini belum diketahui.

\section{b. Patogen memanipulasi proses pasca-translasi komponen sensor asam nukleat}

Ekspresi komponen-komponen yang termasuk ke dalam jalur sinyal RLR diatur sedemikian rupa oleh proses pasca-translasi seperti ubiquitylation dan serine/threonine phosphorylation. Sejumlah virus RNA, seperti DENV, IAV, virus hepatitis C (HCV), severe acure respiratory syndrome (SARS)associatedcoronavirus (SARS-CoV), dan foot-andmouth disease virus (FMDV) berinteraksi secara langsung maupun tidak langsung dengan E3 ubiquitin ligase yang bertanggungjawab terhadap proses ubiquitylation komponen-komponen RIG-I, sehingga akhirnya mencegah aktivasi jalur sinyal RIG-I (Chan \& Gack, 2016).

Hasil penelitian terkini menunjukkan bahwa reverse transcriptase dan polimerase virus hepatitis B (HBV) berikatan dengan STING sehingga menghambat ubiquitylation STING tersebut dan pada akhirnya akan menghambat produksi IFN- $\beta$ (Liu et al., 2015). Berbeda dengan HBV, human herpesvirus 8 (HHV 8) atau yang biasa disebut Kaposi sarcoma-associated herpesvirus (KSHV), juga dapat menghambat aktivasi STING melalui penggunaan molekul virus yang bernama viral interferon regulatory factor 1 (vIRF1). Molekul protein virus ini berinteraksi dengan STING sehingga menghambat proses fosforilasi yang diperantarai oleh TANK-binding kinase 1 (TBK1) dan akhirnya berujung pada penghambatan aktivasi STING (Ma et al., 2015). Selain itu, virus DNA penyebab tumor (oncogenic DNA viruses) seperti human papillomavirus 18 (HPV18) dan human adenovirus 5 (hAd5) telah dilaporkan menghambat jalur sinyal cGAS-STING menggunakan oncoprotein E7 dan E1A, berturutturut (Lau et al., 2015). 


\section{c. Patogen mengekspresikan protein yang dapat memotong atau mendegradasi komponen sensor asam nukleat}

Salah satu langkah efektif yang ditempuh oleh mikroba untuk menghambat jalur sinyal biologis di dalam tubuh inang adalah dengan cara mengeliminasi protein-protein penting yang terlibat dalam jalur sinyal tersebut. Hal yang sama juga berlaku untuk jalur sinyal PRR (Chan \& Gack, 2016). Untuk mencapai tujuan tersebut, beberapa virus mengekspresikan protease yang dapat berinteraksi secara langsung dan memotong protein-protein sinyal RLR. Misalnya, protease $3 \mathrm{C}^{\text {pro }}$ yang diproduksi oleh poliovirus dan EV71 dapat memotong RIG-I sedangkan protease $2 \mathrm{~A}^{\text {pro }}$ yang dimiliki oleh EV71 dapat merusak molekul MDA5 (Barral et al., 2009; Feng et al., 2014).

Selain itu, beberapa virus juga dapat menginduksi degradasi molekul sinyal RLR. Contohnya, poliovirus dapat menginduksi eliminasi MDA5 menggunakan proteasome dan caspase yang terdapat di dalam sel inang (Barral et al., 2007) dan Measles virus $(\mathrm{MeV})$, yang dapat menyebabkan campak pada manusia, dapat menginduksi proses autofagi selektif untuk mendegradasi mitokondria (yang biasa disebut mitofagi) yang pada akhirnya akan menurunkan jumlah mitochondrial antiviral signalling protein (MAVS) yang merupakan komponen penting dalam jalur RLR RIG-I dan MDA5 (Xia et al., 2014). Mekanisme serupa diperlihatkan oleh virus DNA seperti herpes simplex virus 1 (HSV-1). Virus ini memiliki kemampuan untuk menginduksi degradasi IFI16 oleh proteasome untuk mencegah pengenalan genom DNA mereka oleh IFI16 (Orzalli et al., 2012).

\section{PROSPEK AGONIS DAN ANTAGONIS SENSOR ASAM NUKLEAT}

Kemampuan tubuh untuk mendeteksi DNA dan/atau RNA patogen melalui penggunaan berbagai sensor asam nukleat menawarkan potensi yang sangat besar untuk penemuan obat baru sebab beragam target obat baru dapat ditemukan di dalam jalur sinyal sensor asam nukleat tersebut. Saat ini, beberapa senyawa agonis dan antagonis sensor asam nukleattelah mulai dikembangkan untuk digunakan pada penyakit infeksi, kanker, dan autoimun (Junt \& Barchet, 2015).

Pada awalnya, agonis sensor asam nukleat ditujukan untuk mengaktifkan mekanisme efektor antivirus yang diperantarai oleh IFN. Namun, kini telah mulai dilaporkan bahwa senyawa-senyawa agonis tersebut dapat pula mengaktivasi sel dendritik, meningkatkan sekresi sitokin, mendorong maturasisel fagosit, dan menstimulasi presentasi antigen yang lebih baik sehingga indikasi mulai diarahkan sebagai imunostimulator (Junt \& Barchet, 2015). Beberapa agonis sensor asam nukleat telah mulai diuji secara preklinik dan beberapa di antaranya, seperti agonis TLR3, TLR7, TLR8, dan TLR9, telah masuk ke dalam fase pengujian klinik tahap I - III. Bahkan, salah satu agonis TLR7, Imiquimod, telah memperoleh persetujuan resmi dari Food and Drug Administration (FDA) Amerika untuk digunakan dalam menangani kanker kulit (Huen \& Rook, 2014; Junt \& Barchet, 2015).

Selain senyawa agonis, beberapa senyawa antagonis yang dapat menghambat aktivasi sensor asam nukleat telah mulai dikembangkan dan beberapa di antaranya telah memasuki fase pengujian klinik baik pada tahap I, II maupun III. Senyawa-senyawa antagonis tersebut diharapkan dapat digunakan pada berbagai kondisi inflamasi terkait overekspresi IFN seperti yang terjadi pada pasien yang menderita penyakit autoimun (Junt \& Barchet, 2015). Obat-obat yang bersifat antagonis terhadap sensor asam nukleat dapat bekerja melalui tiga cara: netralisasi IFN, eliminasi asam nukleat melalui penggunaan DNase atau RNase rekombinan, atau melalui penghambatan sensor DNA atau sensor RNA maupun komponen-komponen jalur sinyal yang berkaitan. Contoh dan penjelasan lebih detil mengenai senyawa-senyawa agonis dan antagonis sensor asam nukleat dapat dilihat pada artikel Junt and Barchet (2015).

\section{KESIMPULAN}

Saat ini, pengetahuan tentang imunologi dan segala aspek yang berkaitan erat dengan penemuan obat baru beserta target dan mekanisme kerjanya mengalami perkembangan yang sangat pesat. Salah satu topik yang saat ini menjadi pusat perhatian imunologis dan farmakologis adalah mekanisme sel tubuh dalam membedakan asam nukleat patogen dari asam nukleatnya sendiri. Dengan menggunakan berbagai sensor asam nukleat, sel dapat mendeteksi patogen intraseluler dan kemudian menginstruksikan aktivasi sistem imun intrinsik yang selanjutnya akan berujung pada eliminasi asam nukleat patogen melalui jalur stimulasi interferon. Dengan demikian, tubuh dapat mengeliminasi atau mengurangi ancaman 
infeksi letal akibat aktivitas patogen intraseluler. Sayangnya, pada beberapa kondisi, sensor asam nukleat mengalami disorientasi sehingga mengenali DNA atau RNA sel inang sebagai asam nukleat asing yang harus dibasmi. Kejadian ini dapat menginduksi timbulnya berbagai penyakit autoimun. Selain itu, beberapa virus memiliki kemampuan untuk menghindari sensor asam nukleat sehingga replikasi virus tersebut dapat terus terjadi di dalam sel tanpa dapat dicegah. Pada kondisi ini, ancaman infeksi letal pun menjadi tak terhindarkan.

Untuk mengatasi hal tersebut, beberapa pendekatan farmakologis telah mulai dilakukan. Salah satunya adalah melalui penemuan dan pengujian beragam senyawa yang bersifat agonis maupun antagonis terhadap sensor asam nukleat maupun jalur sinyal yang berkaitan. Walaupun demikian, penemuan obat di bidang ini masih dianggap belum terlalu pesat sebab hingga kini hanya satu agonis TLR7 yang telah disetujui oleh FDA untuk beredar di pasaran. Salah satu penyebab langkanya jenis obat yang menjadikan sensor asam nukleat sebagai target kerja adalah belum adanya gambaran komprehensif tentang jalur sinyal yang teraktivasi. Untuk mengatasi hal tersebut, elusidasi jalur sinyal yang berkaitan dengan aktivasi sensor asam nukleat merupakan satu hal yang hendaknya terus dilakukan. Selain untuk mencari target kerja baru, hal ini dapat membantu dalam memprediksi efek samping yang mungkin timbul dalam pengobatan.

\section{UCAPAN TERIMAKASIH}

Penelitian yang dilaksanakan oleh grup FN dibiayai oleh Universitas Hasanuddin menggunakan skema biaya Benua Maritim Indonesia Spesifik (BMIS) dan World Class University (WCU).

\section{DAFTAR PUSTAKA}

Agrawal, N., Dasaradhi, P. V. N., Mohmmed, A., Malhotra, P., Bhatnagar, R. K., \& Mukherjee, S. K. (2003). RNA interference: Biology, mechanism, and applications. Microbiol Mol Biol Rev, 67(4), 657-685.

Alberts, B., Johnson, A., Lewis, J., Morgan, D., Raff, M., Roberts, K., et al. (2014). Molecular Biology of The Cell (6th ed.): Garland Science.

Arandjelovic, S., \& Ravichandran, K. S. (2015). Phagocytosis of apoptotic cells in homeostasis. Nat Immunol, 16(9), 907-917.
Barral, P. M., Morrison, J. M., Drahos, J., Gupta, P., Sarkar, D., Fisher, P. B., et al. (2007). MDA5 is cleaved in poliovirus-infected cells. $J$ Virol, 81(8), 3677-3684.

Barral, P. M., Sarkar, D., Fisher, P. B., \& Racaniello, V. R. (2009). RIG-I is cleaved during picornavirus infection. Virol, 391(2), 171176.

Barton, G. M., \& Kagan, J. C. (2009). A cell biological view of Toll-like receptor function: regulation through compartmentalization. Nat Rev Immunol, 9(8), 535-542.

Bonazzi, M., \& Cossart, P. (2006). Bacterial entry into cells: A role for the endocytic machinery. FEBS Lett, 580(12), 2962-2967.

Broz, P., \& Monack, D. M. (2013). Newly described pattern recognition receptors team up against intracellular pathogens. Nat Rev Immunol, 13(8), 551-565.

Brutscher, L. M., \& Flenniken, M. L. (2015). RNAi and antiviral defense in the honey bee. $J$ Immunol Res, 2015, 10.

Casadevall, A. (2008). Evolution of intracellular pathogens. Annu Rev Microbiol, 62(1), 1933.

Casadevall, A., \& Pirofski, L.-A. (2002). What is a pathogen? Annals of Medicine, 34(1), 2-4.

Chan, Y. K., \& Gack, M. U. (2016). Viral evasion of intracellular DNA and RNA sensing. Nat Rev Microbiol, 14(6), 360-373.

Coltart, C. E. M., Lindsey, B., Ghinai, I., Johnson, A. M., \& Heymann, D. L. (2017). The Ebola outbreak, 2013-2016: old lessons for new epidemics. Philos Trans R Soc Lond B: Biol Sci, 372(1721), 1-24.

Crozat, K., Vivier, E., \& Dalod, M. (2009). Crosstalk between components of the innate immune system: promoting anti-microbial defenses and avoiding immunopathologies. Immunol Rev, 227(1), 129-149.

Dempsey, A., \& Bowie, A. G. (2015). Innate immune recognition of DNA: A recent history. Virol, 479, 146-152.

Desmet, C. J., \& Ishii, K. J. (2012). Nucleic acid sensing at the interface between innate and adaptive immunity in vaccination. Nat Rev Immunol, 12(7), 479-491.

Ding, S.-W. (2010). RNA-based antiviral immunity. Nat Rev Immunol, 10, 632.

Félix, M.-A., Ashe, A., Piffaretti, J., Wu, G., Nuez, I., Bélicard, T., et al. (2011). Natural and 
experimental infection of Caenorhabditis nematodes by novel viruses related to Nodaviruses. PLoS Biol, 9(1), e1000586.

Feng, Q., Langereis, M. A., Lork, M., Nguyen, M., Hato, S. V., Lanke, K., et al. (2014). Enterovirus 2Apro targets MDA5 and MAVS in infected cells. J Virol, 88(6), 3369-3378.

Fire, A., Xu, S., Montgomery, M. K., Kostas, S. A., Driver, S. E., \& Mello, C. C. (1998). Potent and specific genetic interference by doublestranded RNA in Caenorhabditis elegans. Nature, 391(6669), 806-811.

Gao, D., Wu, J., Wu, Y.-T., Du, F., Aroh, C., Yan, N., et al. (2013). Cyclic GMP-AMP synthase is an innate immune sensor of HIV and other retroviruses. Science, 341(6148), 903-906.

Haas, T., Metzger, J., Schmitz, F., Heit, A., Müller, T., Latz, E., et al. (2008). The DNA sugar backbone 2'-deoxyribose determines Tolllike receptor 9 activation. Immunity, 28(3), 315-323.

Hornung, V., \& Latz, E. (2010). Intracellular DNA recognition. Nat Rev Immunol, 10(2), 123130.

Huen, A. O., \& Rook, A. H. (2014). Toll receptor agonist therapy of skin cancer and cutaneous T-cell lymphoma. Curr Opin Oncol, 26(2), 237-244.

Janeway, C. A. (1989). Approaching the asymptote? Evolution and revolution in immunology. Cold Spring Harb Symp Quant Biol, 54, 113.

Jin, T., Perry, A., Jiang, J., Smith, P., Curry, J. A., Unterholzner, L., et al. (2012). Structures of the HIN domain:DNA complexes reveal ligand binding and activation mechanisms of the AIM2 inflammasome and IFI16 receptor. Immunity, 36(4), 561-571.

Junt, T., \& Barchet, W. (2015). Translating nucleic acid-sensing pathways into therapies. Nat Rev Immunol, 15, 529-544.

Kato, H., Takeuchi, O., Mikamo-Satoh, E., Hirai, R., Kawai, T., Matsushita, K., et al. (2008). Length-dependent recognition of doublestranded ribonucleic acids by retinoic acidinducible gene-I and melanoma differentiation-associated gene 5. J Exp Med, 205(7), 1601-1610.

Kawasaki, T., \& Kawai, T. (2014). Toll-Like receptor signaling pathways. Front Immunol, 5, 461.

Kennerdell, J. R., \& Carthew, R. W. (1998). Use of dsRNA-mediated genetic interference to demonstrate that frizzled and frizzled 2 act in the wingless pathway. Cell, 95(7), 10171026.

Lahaye, X., Satoh, T., Gentili, M., Cerboni, S., Conrad, C., Hurbain, I., et al. (2013). The capsids of HIV-1 and HIV-2 determine immune detection of the viral cDNA by the innate sensor cGAS in dendritic cells. Immunity, 39(6), 1132-1142.

Lau, L., Gray, E. E., Brunette, R. L., \& Stetson, D. B. (2015). DNA tumor virus oncogenes antagonize the cGAS-STING DNA-sensing pathway. Science, 350(6260), 568-571.

Lemaitre, B., Nicolas, E., Michaut, L., Reichhart, J.M., \& Hoffmann, J. A. (1996). The dorsoventral regulatory gene cassette spätzle/toll/cactus controls the potent antifungal response in Drosophila adults. Cell, 86(6), 973-983.

Liu, Y., Li, J., Chen, J., Li, Y., Wang, W., Du, X., et al. (2015). Hepatitis B virus polymerase disrupts K63-linked ubiquitination of STING to block innate cytosolic DNA-sensing pathways. J Virol, 89(4), 2287-2300.

Ma, Z., Jacobs, S. R., West, J. A., Stopford, C., Zhang, Z., Davis, Z., et al. (2015). Modulation of the cGAS-STING DNA sensing pathway by gammaherpesviruses. Proc Natl Acad Sci, 112(31), E4306-E4315.

Maillard, P. V., Ciaudo, C., Marchais, A., Li, Y., Jay, F., Ding, S. W., et al. (2013). Antiviral RNA interference in mammalian cells. Science, 342(6155), 235-238.

Mandell, G. L., Bennett, J. E., \& Dolin, R. (2010). Mandell, Douglas and Bennett's Principles and Practice of Infectious Diseases: Churchill Livingstone Elsevier.

Medzhitov, R. (2007). Recognition of microorganisms and activation of the immune response. Nature, 449(7164), 819826.

Medzhitov, R. (2009). Approaching the asymptote: 20 years later. Immunity, 30(6), 766-775.

Medzhitov, R., Preston-Hurlburt, P., \& Janeway, C. A. (1997). A human homologue of the Drosophila Toll protein signals activation of adaptive immunity. Nature, 388(6640), 394397.

Murphy, K. (2011). Janeway's Immunobiology (8th ed.): Garland Science.

Nainu, F., Shiratsuchi, A., \& Nakanishi, Y. (2017). Induction of apoptosis and subsequent 
phagocytosis of virus-infected cells as an antiviral mechanism. Front Immunol, $8(1220)$.

Nainu, F., Tanaka, Y., Shiratsuchi, A., \& Nakanishi, Y. (2015). Protection of insects against viral infection by apoptosis-dependent phagocytosis. J Immunol, 195(12), 56965706.

Nusslein-Volhard, C., \& Wieschaus, E. (1980). Mutations affecting segment number and polarity in Drosophila. Nature, 287(5785), 795-801.

Orzalli, M. H., DeLuca, N. A., \& Knipe, D. M. (2012). Nuclear IFI16 induction of IRF-3 signaling during herpesviral infection and degradation of IFI16 by the viral ICP0 protein. Proc Natl Acad Sci, 109(44), E3008E3017.

Paludan, S. R., \& Bowie, A. G. (2013). Immune sensing of DNA. Immunity, 38(5), 870-880.

Panayidou, S., Ioannidou, E., \& Apidianakis, Y. (2014). Human pathogenic bacteria, fungi, and viruses in Drosophila: Disease modeling, lessons, and shortcomings. Virulence, 5(2), 253-269.

Pichlmair, A., Schulz, O., Tan, C.-P., Rehwinkel, J., Kato, H., Takeuchi, O., et al. (2009). Activation of MDA5 requires higher-order RNA structures generated during virus infection. J Virol, 83(20), 10761-10769.

Ploegh, H. L. (1998). Viral strategies of immune evasion. Science, 280(5361), 248-253.

Rasaiyaah, J., Tan, C. P., Fletcher, A. J., Price, A. J., Blondeau, C., Hilditch, L., et al. (2013). HIV-1 evades innate immune recognition through specific cofactor recruitment. Nature, 503(7476), 402-405.

Ribet, D., \& Cossart, P. (2015). How bacterial pathogens colonize their hosts and invade deeper tissues. Microbe Infect, 17(3), 173183.

Rock, F. L., Hardiman, G., Timans, J. C., Kastelein, R. A., \& Bazan, J. F. (1998). A family of human receptors structurally related to Drosophila Toll. Proc Natl Acad Sci, 95(2), 588-593.

Schlee, M., \& Hartmann, G. (2016). Discriminating self from non-self in nucleic acid sensing. Nat Rev Immunol, 16(9), 566-580.

Silva, M. (2012). Classical Labeling of Bacterial Pathogens According to Their Lifestyle in the Host: Inconsistencies and Alternatives. Front Microbiol, 3(71), 1-7.

Siomi, H., \& Siomi, M. C. (2009). On the road to reading the RNA-interference code. Nature, 457(7228), 396-404.

Sun, L., Wu, J., Du, F., Chen, X., \& Chen, Z. J. (2013). Cyclic GMP-AMP synthase is a cytosolic DNA sensor that activates the type I interferon pathway. Science, 339(6121), 786-791.

Takahasi, K., Yoneyama, M., Nishihori, T., Hirai, R., Kumeta, H., Narita, R., et al. (2008). Nonself RNA-sensing mechanism of RIG-I helicase and activation of antiviral immune responses. Mol Cell, 29(4), 428-440.

Takeuchi, O., \& Akira, S. (2010). Pattern recognition receptors and inflammation. Cell, 140(6), 805-820.

Tokunaga, T., Yamamoto, H., Shimada, S., Abe, H., Fukuda, T., Fujisawa, Y., et al. (1984). Antitumor activity of deoxyribonucleic acid fraction from Mycobacterium bovis BCG. I. Isolation, physicochemical characterization, and antitumor activity. $J$ Natl Cancer Inst, 72(4), 955-962.

Uchida, L., Espada-Murao, L. A., Takamatsu, Y., Okamoto, K., Hayasaka, D., Yu, F., et al. (2014). The dengue virus conceals doublestranded RNA in the intracellular membrane to escape from an interferon response. Sci Rep, 4, 7395.

Unterholzner, L., Keating, S. E., Baran, M., Horan, K. A., Jensen, S. B., Sharma, S., et al. (2010). IFI16 is an innate immune sensor for intracellular DNA. Nat Immunol, 11(11), 997-1004.

Valanne, S., Wang, J.-H., \& Rämet, M. (2011). The Drosophila Toll signaling pathway. $J$ Immunol, 186(2), 649-656.

Wagner, E. K., Hewlett, M. J., Bloom, D. C., \& Camerini, D. (2007). Basic virology: Wiley.

Weber, M., Sediri, H., Felgenhauer, U., Binzen, I., Bänfer, S., Jacob, R., et al. (2015). Influenza virus adaptation PB2-627K modulates nucleocapsid inhibition by the pathogen sensor RIG-I. Cell Host Microbe, 17(3), 309319. doi: 10.1016/j.chom.2015.01.005

Xia, M., Gonzalez, P., Li, C., Meng, G., Jiang, A., Wang, H., et al. (2014). Mitophagy enhances oncolytic measles virus replication by mitigating DDX58/RIG-I-like receptor signaling. J Virol, 88(9), 5152-5164. 
Xu, J., \& Cherry, S. (2014). Viruses and antiviral immunity in Drosophila. Dev Comp Immunol, 42(1), 67-84.

Yan, N., Regalado-Magdos, A. D., Stiggelbout, B., Lee-Kirsch, M. A., \& Lieberman, J. (2010). The cytosolic exonuclease TREX1 inhibits the innate immune response to human immunodeficiency virus type $1 . \quad$ Nat Immunol, 11(11), 1005-1013.

Zamboni, D. S., \& Rabinovitch, M. (2004). Phagocytosis of apoptotic cells increases the susceptibility of macrophages to infection with Coxiella burnetii phase II through down-modulation of nitric oxide production. Infect Immun, 72(4), 2075-2080. 